about six weeks and the punctum proximum of both eyes was then found to be $7 \mathrm{~cm}$. The writing is now quite normal again.

\title{
BIBLIOGRAPHY
}

1. Scheby-Buch.-Arch.f. Ophthal., p. 265, 1871.

2. Moll.-Centralbl.f. prakt Augenheilk, p. 2, 1896.

3. Weber.-Virchow's Arch., Vol. XXV, p. 114b, and Vol. XXVIII, p. 489, 1863.

4. Schmidt-Rimpler.-Klin. Wochenschr., p. 92, 1884. Berlin.

5. Aubertin.-Rev. Gén. d'Ophtal., p. 280, 1903.

6. Lohmann.-Bericht über d. Vers. d. Ophthal. Gesellsch., p. 264, 1908. Heidelberg.

7. Stephenson. - The Ophthalmoscope, p. 13, 1910.

8. Remak.-Centralbl. f. prakt. A ugenheilk., p. 161, 1886.

9. van der Hoeve. - Brit. Jl. of Ophthal., March, 1924.

10. Wiegmann.-Klin. Monatsbl. f. Augenheilk., p. 161, 1886. .

11. Edinger.-Deutsche,med. Wochenschr., 1904 and 1905.

\section{CASE OF SUPERFICIAL AND DEEP LENS CHANGES, ASSOCIATED WITH DEPOSIT OF PIGMENT ON THE CENTRAL AREA OF THE ANTERIOR CAPSULE OF THE LENS}

\author{
BY \\ IoHn Foster, F.R.C.S.(Edin.) \\ WEST HARTLEPOOL
}

My excuse, if one be deemed necessary for reporting this case, is, that it is well known that there is a dearth of references in the matter of congenital abnormalities of the pupillary area. Probably, however, I should not have taken further note of this case, had I not seen, in this journal for June, 1922, a description of seven similar cases by Dr. Ernest Thomson. Anyone interested in this class of case would naturally refer to Dr. Thomson's paper, where the subject is well discussed, with opinions of several leaders in ophthalmology. Many references are given, British, American, and Continental; to these I have nothing to add.

\section{Notes of my case}

Dorothy M., 12 years of age, sent to the town ophthalmic clinic on account of defective sight. Record of vision: R.V.=6/18 2; L.V. $=6 / 18{ }^{3}$; no glass helped. Date January 10,1922 .

Condition under Atropin. Right Eye.-The central area of the pupil is occupied by an almost circular mass of brown pigment with two holes, below the centre, which the sketch shows; the rest of the pupillary area is normal and the edge of the iris is free from any abnormality whatever. Superior to the circular pigment mass, is a whitish radial spoke, sharply defined, with pointed end upwards, it is clearly subcapsular. 
Left Eye.-The condition, as regards pigment, is practically the same as in the right eye; the difference lies in the lens changes, the radial spoke is below the pigment mass, subcapsular clearly, and in addition there is temporally to the pigment another spoke, whitish and similar in shape to the others, but deeply placed in the lens.

General Remarks.-The case whilst differing from Dr. Thomson's cases is, to my mind, quite definitely of the same type; it is

R.

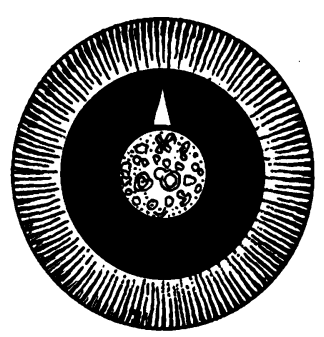

L.

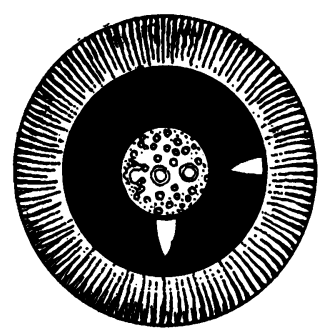

The pupils are fully dilated by atropin.

the only one I have met, out of 3,000 cases examined at the clinic.

History.-The family and personal history is good. No history or sign of syphilis can be found, or history of eye trouble or treatment to the eyes at all. The parents, respectable hardworking people, with a family of ten, were aware that the child had not quite good sight, but did not think there was any need for treatment. With the appearances and the history, the fairest conclusion it is natural to arrive at is, that the case is one of congenital abnormality, quite unconnected with either pre- or postnatal inflammation.

\section{PRESCRIBING SPECTACLES}

BY

\section{A. S. Percival}

NEWCASTLE-UPON-TYNE.

SINCE writing my short paper on this subject which appeared in May, I have found that the expression for the back focal distance (BFD) can be much more simply expressed in the dioptric form.

Let the metre be taken as the unit, and let $\mathrm{D}$ be the power required. Then the thickness $t$ or $3.8 \mathrm{~mm}$. is written $0.0038 \mathrm{~m}$. and $\mathrm{D}$ becomes $-\frac{1}{\mathrm{BFD}}$, and if $d_{1}$ denote the power of the anterior 